\title{
Teori Stres: Stimulus, Respons, dan Transaksional
}

\author{
Nasib Tua Lumban Gaol ${ }^{1}$ \\ National Taiwan Ocean University (NTOU)
}

\begin{abstract}
This paper presents an analysis based on several literature reviews. It aims to understand the basic concept of stress. Understanding the fundamental concept of stress is necessary due to it leads to comprehending deeply regarding what stress is. Principally, there models of stress confirm what stress is and how stress occurs on human. First, the stimulus model of stress is the treating environments that stimulate individual to perceive stress. Second, the response model of stress is a bodily reaction to the source of stress. Third, the transactional model of stress is the evaluation process to the sources of stress between person and treating environment. Accordingly, stress can occur when individual deals with the unexpected environments or threatening situations. Stress can become eustress (positive) or distress (negative) for someone who perceives stress. If the ability to deal with stress is not sufficient and demands are excessive, stress will increase continuously. Consequently, stress contributes negatively on physical and psychological health. Therefore, the awareness toward stress and its symptoms is likely to avoid from the negative consequence of stress.
\end{abstract}

Keywords: distress, eustress, health, theory of stress

\section{Pengantar}

Stres merupakan masalah umum yang terjadi dalam kehidupan umat manusia. Kupriyanov dan Zhdanov (2014) menyatakan bahwa stres yang ada saat ini adalah sebuah atribut kehidupan modren. Hal ini dikarenakan stres sudah menjadi bagian hidup yang tidak bisa terelakkan. Baik di lingkungan sekolah, kerja, keluarga, atau dimanapun, stres bisa dialami oleh seseorang. Stres juga bisa menimpa siapapun termasuk anak-anak, remaja, dewasa, atau yang sudah lanjut usia. Dengan kata lain, stres pasti terjadi pada siapapun dan dimanapun. Yang menjadi masalah adalah apabila jumlah stres itu begitu banyak dialami seseorang. Dampaknya adalah stres itu membahayakan kondisi fisik dan

\footnotetext{
1 Korespondensi mengenai artikel ini dapat dilakukan melalui: nasibgaol.jo@gmail.com
}

mentalnya. Lin dan Huang (2014) menyatakan bahwa stres yang jumlahnya begitu banyak bisa membahayakan kepada setiap orang, termasuk siswa.

Dalam lingkungan akademik, stres merupakan pengalaman yang paling sering dialami oleh para siswa, baik yang sedang belajar di tingkat sekolah ataupun di perguruan tinggi. Hal tersebut dikarenakan banyaknya tuntutan akademik yang harus dihadapi, misalnya ujian, tugas-tugas, dan lain sebagainya. Sejumlah peneliti telah menemukan bahwa siswa yang mengalami stres akan cenderung menunjukkan kemampuan akademik yang menurun (Rafidah, Azizah, Norzaidi, Chong, Salwani, \& Noraini, 2009; Talib \& Zia-ur-Rehman, 2012), kesehatan yang memburuk (Chambel \& Curral, 2005; Marshall, Allison, Nyakap \& Lanke, 2008), depresi (Das \& Sahoo, 2012; Jayanthi, Thirunavukarasu \& Rajkumar, 
2015), dan gangguan tidur (Waqas, Khan, Sharif, Khalid \& Ali, 2014). Dengan keberadaan stres yang tidak bisa terelakkan oleh setiap orang, maka pemahaman mendalam tentang stres sangatlah diperlukan. Oleh karena itu, tulisan ini bermaksud untuk menghadirkan penjelasan tentang teori stres dan dampak yang ditimbulkan oleh stres.

\section{Sejarah Istilah "Stres"}

Sekitar awal abad keempat belas, istilah stres bisa ditemukan, namun pengertiannya masih pada "kesulitan atau penderitaan yang begitu berat". Istilah stres tersebut pun masih berdasarkan penekanan yang belum secara sistematis (Lazarus, 1993). Kemudian pada abad kedelapan belas hingga awal abad kesembilan belas, kata stres dipahami sebagai kekuatan, tekanan, ketegangan atau usaha yang kuat diberikan pada sebuah objek material atau pada seseorang "organ atau kekuatan mental" (Hinkle, 1974). Pada abad kesembilan belas, istilah stres juga sebenarnya sudah mulai digunakan dalam ilmu kesehatan dan sosial (Bartlett, 1998). Namun istilah stres baru dikaitkan pada kondisi manusia di bidang kajian-kajian ilmiah semajak tahun 1930 (Lyon, 2012). Kemudian selama abad kesembilan belas hingga abad kedua puluh, istilah stres dan tekanan pun mulai dikosep sebagai penyebab permasalahan dalam kesehatan secara fisik maupun psikologis (Hinkle, 1974).

Cannon merupakan peneliti pertama yang mengembangkan konsep stres yang dikenal dengan "fight-or-flight response" pada tahun 1914 (Bartlett, 1998). Berdasarkan konsep yang diperkenalkan Cannon tersebut, "the fight-or-flight response", stres diartikan sebagai respons tubuh terhadap sesuatu hal. Cannon menyatakan bahwa stres adalah sebagai ganguan homeostasis yang menyebabkan perubahan pada keseimbangan fisiologis yang dihasilkan dari adanya rangsangan terhadap fisik maupun psikologis. Namun seiring dengan kemajuan ilmu pengetahun dan bertambahnya penelitian di bidang stres, berbagai teori tentang stres pun bermunculan. Beberapa teori tersebut diantaranya: (1) Person-Environment Fit, (2) Conservation of Resources Theory, dan (3) The Job DemandsControl-support Model of Work Design (Dewe, O'Driscoll \& Cooper, 2012).

Walaupun teori stres terus berkembang dari masa ke masa, tetapi secara fundamental teori stres hanya digolongkan atas tiga pendekatan. Tiga pendekatan terhadap teori stres tersebut adalah: (1) stres model stimulus (rangsangan), (2) stres model response (respons), dan (3) stres model transactional (transaksional) (Bartlett, 1998; Lyon, 2012). Tulisan ini akan membahas konsep stres, stimulus, respon, dan akibat yang ditimbulkan oleh stres.

\section{Pembahasan}

\section{Stres Model Stimulus}

Stres model stimulus menjadi terkenal pada tahun 1940 dan 1950 (Bartlett, 1998). Kemudian pada tahun 1960-an, para ahli psikologi menjadi tertarik untuk mengkaji konsep stres yang ditinjau dari pengalaman psikologis (Lyon, 2012). Sebenarnya, perkembangan teori stres model stimulus berawal dari temuan para peneliti terhadap prajurit militer yang sedang melaksanakan tugas perang (Bartlett, 1998). Tugas kemiliteran ini pun dianggap sebagai penyebab stres yang menyebabkan semakin memburuknya kesehatan para militer tersebut. Kondisi kesehatan yang memburuk itu disebabkan oleh adanya rangsangan atau stimulus yang datang dari luar diri mereka. Rangsangan tersebut merupakan situasi peperangan yang akan dihadapi. Mereka membayangkan bahwa situasi peperangan yang akan terjadi adalah sangat berbahaya. Alhasil, karena mereka banyak memikirkan 
hal tersebut kesehatan mereka pun cenderung memburuk.

Stres model stimulus merupakan model stres yang menjelaskan bahwa stres itu adalah varibel bebas (independent) atau penyebab manusia mengalami stres (Lyon, 2012). Atau dengan kata lain, stres adalah situasi lingkungan yang seseorang rasakan begitu menekan (Bartlett, 1998) dan individu tersebut hanya menerima secara langsung rangsangan stres tanpa ada proses penilaian (Staal, 2004). Penyebab-penyebab stres tersebut berperan dalam menentukan seberapa banyak stres yang akan mungkin diterima. Oleh karena itu, tekanan yang berasal dari situasi-situasi lingkungan bisa bertindak sebagai penyebab dan penentu pada gangguan-ganguan kesehatan apabila terjadi dalam kurun waktu yang sering dan dengan jumlah yang berbahaya (Bartlett, 1998). Adapun situasi-situasi yang memungkinkan menjadi pemicu terjadinya stres adalah beban kerja, kepanasan, kedinginan, suara keributan, ruangan yang berbau menyengat, cahaya yang terlalu terang, lingkungan yang kotor, ventilasi yang tidak memadai, dan lain sebagainya (Staal, 2004; Hariharan \& Rath, 2008).

Bartlett (1998) menegaskan bahwa stres stimulus lebih memfokuskan pada sumbersumber stres dari pada aspek-aspek lainnya. Sumber stres tersebut dikenal dengan istilah "stressor". Sebenarnya, stressor hanya memberikan rangsangan dan mendorong sehingga terjadi stres pada seseorang. Stressor berperan sebagai pemicu stres pada individu. Menurut Thoits (1994), sumber stres (stressor) dapat dikategorikan menjadi tiga jenis, yaitu (1) life events (peristiwaperistiwa kehidupan), (2) chronic strain (ketegangan kronis), dan (3) daily hassles (permasalahan-permasalahan sehari-hari).

Life events (peristiwa-peristiwa kehidupan) berfokus pada peranan perubahanperubahan kehidupan yang begitu banyak terjadi dalam waktu yang singkat sehingga meningkatkan kerentanan pada penyakit (Lyon, 2012). Suatu peristiwa kehidupan bisa menjadi sumber stres terhadap seseorang apabila kejadian tersebut membutuhkan penyesuaian perilaku dalam waktu yang sangat singkat (Thoits, 1994). Ketika seseorang gagal berurusan (menyesuaikan) dengan situasi atau perubahan-perubahan yang secara ekstrem tesebut, maka timbullah dampak buruk, misalnya perasaan cemas.

Spurgeon, Jackson dan Beach (2001) melakukan penelitian kepada 115 karyawan yang berusia dari 16 tahun sampai 56 tahun di area United Kingdom dengan menggunakan the Life Events Inventory (LEI). Spurgeon et al. (2001) menemukan bahwa ada sepuluh peristiwa kehidupan yang paling penting dan bisa memicu terjadinya stres, yaitu kematian pasangan, perceraian, kehilangan anggota keluarga, terpenjara, masalah keuangan, pertengkaran dalam keluarga, tunawisma, pengangguran, anggota keluarga yang tiba-taba mencoba bunuh diri, dan anggota keluaga yang menderita sakit serius. Hasil penelitian lainnya, Oswalt dan Riddock (2007) melaporkan bahwa peristiwa kehidupan bisa juga menjadi sumber stres terhadap siswa ketika mereka baru mulai memasuki masa perkuliahan. Hal tersebut terjadi karena para siswa tersebut perlu menyesuaikan diri dengan lingkungan baru yang sedang mereka hadapi.

Chronic strains (ketegangan kronis) merupakan kesulitan-kesulitan yang konsisten atau berulang-ulang terjadi dalam kehidupan sehari-hari. Ketegangan kronis bisa mempengaruhi terhadap kesehatan manusia termasuk fisik maupun psikologis (Thoits, 1994). Hal tersebut dikarenakan ketegangan kronis yang terus berlanjut dan menjadi ancaman kepada seseorang (Serido, Almeida \& Wethington, 2004). Serido et al. 
(2004) melakukan penelitian terhadap 1.031 warga Amerika Serikat yang berusia dari 25 sampai 74 tahun. Mereka menemukan ada empat faktor yang menjadi pemicu terjadinya ketegangan kronis, yaitu tuntutantuntutan pekerjaan, kurangnya pengendalian atas pekerjaan, tuntutan-tuntutan dari rumah, kurangnya pengendalian dari rumah. Sedangkan di lingkungan akademik, ketegangan kronis bisa dipicu karena banyak hal, misalnya adalah tekanan akademik (Oswalt \& Riddock, 2007).

Daily hassles (permasalah sehari-hari) adalah peristiwa-peristiwa kecil yang terjadi dalam kehidupan sehari-hari yang memerlukan tindakan penyesuaian dalam sehari saja (Thoits, 1994). Misalnya, seseorang mengalami kesulitan-kesulitan, dan kesulitan tersebut tidak berlanjut secara terus menerus. Kesulitan yang dihadapi itupun bisa terselesaikan dalam kurun waktu yang singkat. Ada beberapa contoh dari permasalah sehari-hari, misalnya pendatang yang tidak diharapkan, kemacatan berlalu lintas, berkomunikasi dengan orang lain, tugastugas keseharian yang penting, tenggat waktu yang tiba-tiba dan berargumentasi kepada orang lain (Thoits, 1994; Serido, et al., 2004). Permasalahan-permasalahan tersebut hanya menimbulkan stres sesaat dan tidak mengakibatkan terjadinya gangguan-gangguan fisik maupun mental yang parah.

\section{Stres Model Respons}

Stres model respons dikembangkan oleh Hans Selye. Selye adalah ahli yang dikenal luas karena penelitian dan teorinya tentang stres yang berkaitan dengan aspek fisik dan kesehatan (Lyon, 2012). Merujuk pada Bartlett (1998), pada tahun 1946, Selye menulis sebuah karya ilmiah yang berjudul "The General Adaptation Syndrome and Diseases of Adaptation" dan menggunakan istilah stres untuk mengacu secara khusus pada tekananan yang berasal dari luar individu. Namun, empat tahun kemudian, yaitu di tahun 1950, Selye mengganti defenisi stres tersebut menjadi respons seseorang terhadap stimulus yang diberikan. Selye menekankan bahwa stres merupakan reaksi atau tanggapan tubuh yang secara spesifik terhadap penyebab stres yang mana mempengaruhi kepada seseorang.

Lyon (2012) mengistilahkan reaksi tubuh terhadap sumber stres sebagai variable terikat atau hasil. Hasil stres itu bersumber dari dalam diri individu (Staal, 2004). Hasil stres itupun meliputi perubahan kondisi psikis, emosional, dan psikologis (Carr \& Umberson, 2013). Misalnya, ketika seseorang mengalami situasi yang mengkhawatirkan, tubuh secara spontan bereaksi terhadap ancaman tersebut. Ancaman tersebut termasuk sumber stres, dan respons tubuh terhadap ancaman itu merupakan stres respons (Scheneidrman, Ironson \& Siegel, 2005). Dengan demikian, perpaduan antara sumber stres dan hasil stres mengarahkan pada pengertian bahwa stres tidak bisa dipisahkan dari reaksi tubuh terhadap sumber-sumber stres yang ada. Atau dengan kata lain, tubuh tidak akan memberikan respon apapun kalau tidak ada rangsangan. Oleh karena itu, stres respons dapat disimpulkan sebagai reaksi tubuh secara jasmaniah terhadap sumber-sumber stres yang ada atau rangsangan yang menyerang tubuh.

Untuk mengetahui lebih lanjut bagaimana tubuh memberikan respons terhadap sumber stress, Selye pun memperkenalkan sebuah model stress. Adapun model stress yang diperkenalkan Selye adalah General Adaptation Syndrome atau disingkat dengan istilah GAS (Rice, 2011). Sesuai pada GAS (Gambar 1.), ada tiga tahapan stres respons, yaitu (1) alarm (tanda bahaya), (2) resistance (perlawanan), dan (3) exhaustion (kelelahan). Tahapan pertama stres respons dalam 
General Adaptation Syndrome adalah alarm. Alarm merupakan suatu kondisi yang tidak diinginkan dan terjadi ketika ada perbedaan antara kenyataan yang sedang terjadi dan situasi yang diharapkan (Ursin \& Eriksen, 2004). Sebagai akibatnya, tubuh menerima rangsangan dan secara alami mengaktifkan reaksi flight-or-fight karena adanya kondisi yang berpotensi mengancam kestabilan kondisi tubuh (Lyon, 2012). Pada tahap pertama ini akan timbul seperti sakit di dada, jantung berdebar-debar, sakit kepala, disfagia (kesulitan menelan), kram, dan lain sebagainya (Rice, 2011).

Tahapan kedua dari General Adaptation Syndrome adalah resistance (perlawanan). Perlawanan terjadi saat alarm tidak berakhir atau terus menerus berlangsung. Dampaknya, kekuatan fisik pun dikerahkan untuk melanjutkan kerusakan-kerusakan karena rangsangan-rangsangan yang membahayakan sedang menyerang (Lyon, 2012). Peristiwa ini terjadi karena pada tahap kedua terjadi konflik dengan tahap pertama (Rice, 2011). Oleh karena itu, selama proses perlawanan di tahap resistance ada kemungkinan akan timbulnya penyakit, seperti radang sendi, kanker, dan hipertensi (Lyon, 2012).

Ketika stres masih berlangsung terusmenerus, maka selanjutnya stres berada pada pada tahap terakhir. Berdasarkan General Adaptation Syndrome, di tahap ketiga ini tubuh sudah merasakan exhaustion (kelelahan) (Lyon, 2012). Kondisi ini dikarenakan tubuh benar-benar tidak sanggup lagi mengadakan perlawanan terhadap sumber stres. Atau dengan kata lain, tubuh sudah menyerah karena kehabisan kemampuan untuk menghadapi serangan yang mengancam. Oleh karena itu, pada tahap ketiga ini, menurut Lyon (2012) dan Rice (2011) organ-organ tubuh bisa berhenti berfungsi atau bisa mengakibatkan kematian pada seseorang.

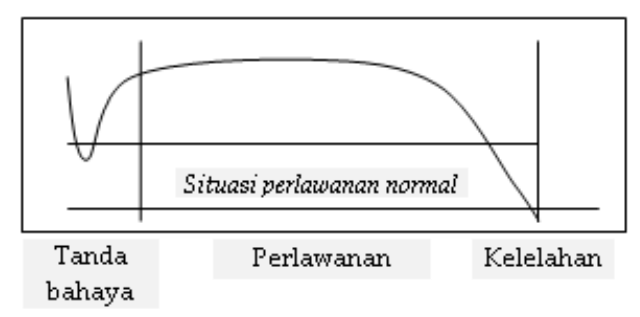

Gambar. 1 Model pada General Adaptation Syndrome (GAS). ( Rice, 2011, hlm. 24)

\section{Stres Model Transaksional}

Stres model transaksional berfokus pada respon emosi dan proses kognitif yang mana didasarkan pada interaksi manusia dengan lingkungan (Jovanovic, Lazaridis \& Stefanovic, 2006). Atau dengan kata lain, stres model ini menekankan pada peranan penilaian individu terhadap penyebab stres yang mana akan menentukan respon individu tersebut (Staal, 2004).

Richard Lazarus dan Susan Folkman adalah tokoh yang terkenal dalam mengembangkan teori stres model transaksional. Lazarus dan Folkman (1984) menyatakan bahwa stres adalah hubungan antara individu dengan lingkungannya yang dievaluasi oleh seseorang sebagai tuntutan atau ketidakmampuan dalam mengahadapi situasi yang membahayakan atau mengancam kesehatan. Lebih lanjut, Lazarus dan Folkman menegaskan bahwa appraisal adalah faktor utama dalam menentukan seberapa banyak jumlah stres yang dialami oleh seseorang saat berhadapan dengan situasi berbahaya (mengancam). Dengan kata lain, stres adalah hasil dari terjadinya transaksi antara individu dengan penyebab stres yang melibatkan proses pengevaluasian (Dewe et al., 2012). Selain itu, sumber stres merupakan kejadian atau situasi yang melebihi kemamampuan pikiran atau tubuh saat berhadapan dengan sumber stres tersebut. Ketika situasi tersebut memberikan rangsangan, maka indi- 
vidu akan melakukan appraisal (penilaian) dan coping (penanggulangan). Oleh karena itu, stres bisa berlanjut ke tahap yang lebih parah atau sedikit demi sedikit semakin berkurang. Hal tersebut ditentukan bagaimana usaha seseorang berurusan dengan sumber stres.

Appraisal atau proses penilaian adalah suatu tindakan pengevaluasian, penafsiran, dan tanggapan tentang peristiwa-persitiwa yang ada (Olff, Langeland \& Gersons, 2005). Merujuk pada Lazarus dan Folkman (1984), ada dua tahap penilaian yang dilakukan oleh manusia ketika sedang mengalami stres yaitu: (1) primary appraisal dan (2) secondary appraisal. Penilaian tahap awal (primary appraisal) dilakukan oleh individu pada saat mulai mengalami sesuatu peristiwa. Secara khusus, individu mengevaluasi pengaruh yang memungkinkan timbul dari adanya tuntutan-tuntutan terhadap sumber daya yang ada pada kondisi kesehatan (Lyon, 2012). Lazarus dan Folkman (1984) membagi proses primary appraisal ini dalam tiga tahap, yaitu (1) irrelevant, (3) benign-positive, dan (3) stressful.

Irrelevant (tidak berkaitan) terjadi ketika seseorang berhadapan dengan situasi yang tidak memberikan dampak apapun terhadap kesejahteraan (kesehatan) seseorang. Dengan kata lain, seseorang tidak membutuhkan usaha apapun ketika menghadapi sebuah permasalahan atau kejadian karena tidak ada yang dihilangkan dan diterima dalam proses transaksi ini. Benign-positive (berdampak baik) terjadi ketika hasil dari pertempuran berdampak positif pada peningkatan kesejahteraan individu. Sebagai hasilnya, akan timbul luapan perasaan emosi seperti bahagia, kasih, senang, dan sebagainya. Stressful terjadi ketika individu tidak lagi memiliki kemampuan secara personal untuk menghadapi penyebabpenyebab stres. Sebagai akibatnya individu akan mengalami (1) harmful, (2) threatening, dan (3) challenging. Harm/loss adalah tanda bahwa sesuatu yang membahayakan sedang terjadi pada. Threat adalah tanda bahwa adanya kemungkinan-kemungkinan yang membahayakan itu akan berlanjut dikemudian hari. Challenge merupakan keterlibatan individu dengan tuntutan yang ada. Tantangan-tantangan tesebut menimbulkan emosi seperti pengharapan, keinginan dan keyakinan (Lazarus \& Folkman, 1984).

Secondary appraisal atau penilaian tahap kedua adalah proses penentuan jenis coping yang bisa dilakukan dalam mengahadapi situasi-situasi yang mengancam (Lyon, 2012). Coping tergantung pada penilaian terhadap hal apa yang bisa dilakukan untuk mengubah situasi (Lazarus, 1993). Lazarus dan Folkman (1984) membagi dua metode coping (penanggulangan) yang dilakukan ketika menghadapi stres yaitu (1) problemfocused coping (penanggulangan berfokus pada masalah) dan (2) emotion-focused coping (penanggulangan berfokus pada emosi).

Problem-focused coping adalah cara menanggulangi stres dengan berfokus pada permasalahan yang dihadapi. Coping yang berfokus pada masalah ini bisa dilakukan apabila masih ada memungkinkan melakukan sesuatu hal (Lazarus, 1993) untuk menanggulangi stres. Atau dengan kata lain, problem-focused coping dilakukan untuk menghidari atau mengurangi stres dengan cara langsung menghadapi sumber stres atau masalah yang terjadi. Emotion-focused coping adalah cara penanggulangan stres dengan melibatkan emosi. Atau dengan kata lain, seseorang yang mengalami stres akan melibatkan emosinya dan menggunakan peniliannya terhadap sumber-sumber stres yang ada. Coping yang berfokus pada emosi dilakukan karena tidak ada lagi yang bisa dilakukan (Lazarus, 1993) terhadap sumber stres. Dengan demikian dapat disimpulkan bahwa penanggulangan stres 
yang berfokus pada masalah adalah berurusan dengan situasi secara langsung. Sedangkan penanggulangan stres yang berfokus pada emosi berususan dengan diri sendiri.

\section{Akibat dari Stres}

Sebenarnya stres tidak selalu memberikan dampak negatif karena stres juga bisa berdampak positif kepada manusia. Stres ibarat dua sisi mata uang logam, yaitu memiliki sisi baik dan sisi buruk. Stres yang memberikan dampak positif diistilahkan dengan Eustress, dan stres yang memberikan dampak negatif distilahkan dengan distress (Gadzella, Baloglu, Masten \& Wang, 2012). Kupriyanov dan Zhdanov (2014) menyimpulkan bahwa hasil reaksi tubuh terhadap sumber-sumber stres merupakan eustress. Ketika eustress (stres yang berdampak baik) dialami seseorang, maka terjadilah peningkatan kinerja dan kesehatan (Greenberg, 2006). Sebaliknya ketika seseorang mengalami distress (stres yang berdampak buruk), maka mengkibatkan semakin buruknya kinerja, kesehatan dan timbul gangguan hubungan dengan orang lain.

Pada gambar 2, kurva Yerkes-Dodson menunjukkan bagaimana perbedaan antara distress dan eustress. Mengacu pada kurva Yerkes-Dodson Curve, Le Fevre, Matheny dan Kolt (2003) menginterpretasikan bahwa stres yang bisa berdampak positif (eustress) terhadap kesehatan dan kinerja adalah pada saat stres itu tidak melebihi tingkat maksimal. Sedangkan stres yang yang berlebihan atau melebihi tingkat maksimal bisa memberikan dampak negatif (distress) terhadap kinerja dan kesehatan. Timbulnya stres yang berdampak postif atau negatif ditentukan oleh jumlah tuntutan-tuntutan yang diterima dan kemampuan yang tersedia baik secara fisik dan psikologis untuk menghadapi sumber stres.

Sejumlah peneliti telah melakukan penginvesitigasian tentang dampak yang bisa ditimbulkan oleh stres terhadap manusia. Misalnya, Jarinto (2010) meneliti para karyawan yang ada di Tailand. Penelitian tersebut melibatkan 160 karyawan yang sudah bekerja minimal selama satu tahun di perusahaan. Jarinto (2010) menemukan bahwa eustress merupakan faktor penentu yang mendorong karayawan untuk mencapai kinerja maksimal dan adanya peningkatan kepuasan kerja. Selain itu, jumlah distress yang begitu banyak

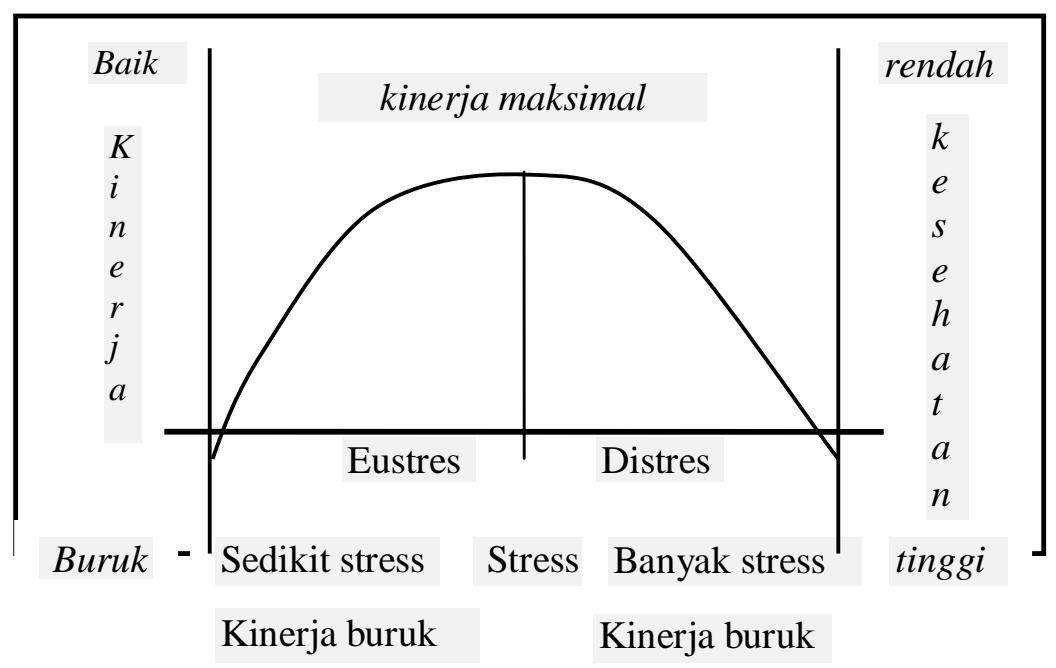

Gambar 2. Kurva Yerkes-Dodson (Greenberg, 2008, hlm. 69) 
secara signifikan berkontribusi mendorong terjadinya penyakit baik secara fisik maupun psikologis terhadap karyawan tersebut.

Jovanovic, Lazaridis dan Stefanovic (2006) mengklasifikasikan gejala atau tanda yang di alami karyawan apabila mereka mengalami stres. Pertama adalah gejala stres berkaitan dengan fisik, yaitu: sakit kepala, masalah pencernaan, kurang tidur, gatalgatal, nyeri ulu hati, keringat malam, keinginan seksual yang berkurang, ketidakteraturan menstruasi, nyeri punggung kronis, otot tegang, kehilangan nafsu makan, berat badan. Kedua adalah gejala stres yang berkaitan dengan emosional atau mental, yaitu: peningkatan kemarahan, frustrasi, depresi, kemurungan, kecemasan, masalah dengan memori, kelelahan, dan peningkatan penggunaan nikotin, alkohol dan obat-obatan. Ketiga adalah gejala stres berkaitan dengan kerja, yaitu: peningkatan absensi, kecelakaan pada pekerjaan, keluhan dari rekan kerja, penurunan kerja produktivitas, kesulitan dalam memahami peraturan kantor, absensi dari pekerjaan, mengambil waktu rehat terlalu lama, waktu pribadi yang berlebihan pada telepon atau internet.

Dalam lingkungan akademik telah ditemukan bahwa stres dapat berdampak positif kepada siswa. Stres bisa berkontribusi positif kalau jumlah stres tersebut adalah normal. Rafidah, et al. (2009) menyatakan bahwa sebenarnya stres itu bisa mempengaruhi aktifitas belajar dan memori seseorang. Dalam proses belajar, dampak positif stres bisa dirasakan oleh siswa apabila jumlah stres tersebut tidak melebihi kemampuan mereka. Jumlah stres yang cukup atau normal itu sangatlah perlu karena bisa mengaktifkan kinerja otak. Schwabe dan Wolf (2012) menemukan bahwa stres bisa menyebabkan berfungsinya beberapa sistem memori pada otak manusia. Penelitian tersebut membuktikan bahwa setelah seseorang menerima stres, sistem berbasis corpus striatum (pusat saraf yang berada di dalam otak hemisphere dekat thalamus) dapat menggeser sistem berbasis hippocampus (bagian sistem limbik yang bertugas penyimpan memori) untuk membantu kinerja tugas-tugas yang ada di dalam otak. Atau dengan kata lain, dengan adanya stress yang diterima, kemampuan simtem-sistem yang ada di otak pun bisa bekerja dengan optimal.

Dampak negatif stres (distress) bisa dirasakan oleh siswa ketika stres tersebut melebihi kemampuan mereka untuk berurusan dengannya. Secara khusus, stres bisa berdampak negatif terhadap kondisi belajar dan kemampuan kognitif siswa. Penelitian Stallman (2010) yang melibatkan 6.479 siswa di Australia mengungkapkan bahwa distress berkaitan dengan ketidakmampuan dan penurunan prestasi akademik pada siswa. Selain itu, Palmer (2013) juga melakukan penelitian kepada sejumlah siswa di wilayah New York Metropolitan, Amerika Serikat. Hasil penelitian Palmer mengungkapkan bahwa ada hubungan negatif antara fatique (kelelahan) dan stres siswa. Dengan adanya hubungan kelelahan dan stres siswa, maka terdapat juga pengaruh yang negatif terhadap proses belajar dan kemampuan kognitif para siswa.

Lebih lanjut, beberapa peneliti lain telah menemukan bahwa stres bisa mengakibatkan siswa merasa depresi (Jayanthi et al., 2015), kemampuan yang memburuk (Talib \& Zia-ur-Rehman, 2012), penurunan prestasi akademik (Stallman, 2010), dan kondisi kesehatan yang memburuk (Marshall, Allison, Nyakap \& Lanke, 2008). Ketika siswa merasakan stres, maka gejala yang timbul adalah seperti perasaan cemas, kegelisahan, keram di leher atau bahu, sakit kepala, kesulitan dalam bernafas, selalu berpikir, kesulitan dalam berkonsentrasi, terlalu mencemaskan banyak hal, dan 
mengkomsumsi obat-obatan secara berlebihan (Aggolla \& Ongori, 2009). Penelitian yang dilakukan Carton dan Goodboy (2015) menemukan bahwa siswa yang mengalami depresi, cemas, dan stres secara berlebih akan cenderung kurang terlibat dalam berinteraksi di dalam kelas.

\section{Penutup}

Stres merupakan pengalaman hidup yang pasti dialami oleh setiap orang. Pada dasarnya, hanya ada tiga teori mendasar yang menjelaskan bagaimana stres itu terjadi pada manusia, yaitu: stres model stimulus, stres model respons, dan stres model transaksional. Ketiga teori tersebut menjelaskan apa yang dimaksud dengan stres dan bagaimana sebenarnya stres itu terjadi pada individu. Stres dikatakan sebagai stimulus ketika ada berbagai rangsangan-rangsangan yang menggangu atau membahayakan. Stres dikatakan sebagai respons saat tubuh bereaksi terhadap sumber-sumber stres. Stres dikatakan transaksional saat adanya proses pengevaluasian dari sumber stres yang terjadi.

Stres tidak hanya berdampak buruk kepada manusia, tetapi stres bisa juga berkontribusi secara positif. Akibat yang ditimbulkan stres terhadap seseorang ditentukan bagaimana kemampuan dan sumber stress yang diterima. Oleh karena itu, ketika jumlah sumber stres begitu banyak, dan kemampuan untuk berurusan dengan stres sedikit, maka stres akan memberikan dampak negatif. Jenis stres yang bersifat tidak baik ini adalah distress. Sebaliknya apabila sumber stres dalam kapasitas yang cukup dan sebanding dengan kemampuan, maka stres akan berdampak positif terhadap kesehatan dan kinerja seseorang. Jenis stres yang bersifat baik ini adalah eustress. Dengan demikian, konsep stres dan tandatanda yang ditimbulkan oleh stres adalah perlu dipahami secara baik. Hal tersebut bertujuan supaya terhindar dari dampak stres yang semakin buruk terhadap fisik maupun psikologis.

\section{Daftar Pustaka}

Agolla, J. E., \& Ongori, H. (2009). An assessment of academic stress among undergraduate students: The case of university of Botswana. Educational Research and Reviews, 4(2), 63-70.

Bartlett, D. (1998). Stress: Perspectives and processes. Philadelphia, USA: Open University Press.

Carr, D., \& Umberson, D. (2013). The social psychology of stress, health, and coping. In DeLameter, J. \& Ward, A. (Eds.). Handbook of Social Psychology (pp. 465-487). Netherlands: Springer.

Chambel, M. J., \& Curral, L. (2005). Stress in academic life: Work characteristics as predictors of student well-being and performance. Applied Psychology, 54(1), 135-147. doi: 10.1111/j.1464-0597.2005. 00200.x.

Carton, S. T., \& Goodboy, A. K. (2015). College students' psychological wellbeing and interaction involvement in class. Communication Research Reports, 32(2), 180-184. doi: 10.1080/08824096. 2015.1016145.

Das, P. P. P., \& Sahoo, R. (2012). Stress and depression among post-graduate students. International Journal ofScientific and Research Publication, 2(7), 1-5.

Dewe, P. J., O’Driscoll, M. P., \& Cooper, C. L. (2012). Theories of psychological stress at work. In Gatchel, R. J. \& I. Z. Schultz, I. Z. (eds.) Handbooks in health, work, and disability (pp. 23-38). USA: Springer.

Gadzella, B. M., Baloglu, M., Masten, W. G., \& Wang, Q. (2012). Evaluation of the 
student life-stress inventory-revised. Journal of Instructional Psychology, 39(2), 82-91.

Greenberg, J. S. (2006). Comprehensive stress management $10^{\text {th }}$ edition. New York, USA: McGraw-Hill Compenies, Inc.

Hariharan, M., \& Rath, R. (2008). Coping with life stress: The Indian experience. India: SAGE Publications India Pvt Ltd.

Hinkle, L. E. (1974). The concept of stress in the biological and social sciences. The International Journal of Psychiatry in Medicine, 5(4), 335-357. doi: 10.2190/ 91dk-nkad-1xp0-y4rg.

Jarinto, K. (2010). Eustress: A key to improving job satisfaction and health among thai managers comparing us, japanese, and thai companies using SEM analysis. NIDA Development Journal, 50(2), 100-129.

Jayanthi, P., Thirunavukarasu, M., \& Rajkumar, R. (2015). Academic stress and depression among adolescents: A cross-sectional study. Indian Pediatrics, 52(3), 217-219.

Jovanovic, J., Lazaridis, K., \& Stefanovic, V. (2006). Theoretical approaches to problem of occupational stress. Acta Facultatis Medicae Naissensis, 23(3), 163169.

Kupriyanov, R., \& Zhdanov, R. (2014). The eustress concept: Problems and outlooks. World Journal of Medical Sciences, 11(2), 179-185. doi: 10.5829/idosi.wjms. 2014.11.2.8433.

Lazarus, R. S. (1993). From psychological stress to the emotions: A history of changing outlooks. Annual review of psychology, 44, 1-21.

Lazarus, R. S., \& Folkman, S. (1984). Stress, appraisal, and coping. New York, USA: Springer Publishing Company.
Le Fevre, M., Matheny, J., \& Kolt, G. S. (2003). Eustress, distress, and interpretation in occupational stress. Journal of Managerial Psychology, 18(7), 726-744.

Lin, S. H., \& Huang, Y. C. (2014). Life stress and academic burnout. Active Learning in Higher Education, 15(1), 77-90. doi: $10.1177 / 1469787413514651$

Lyon, B. L. (2012). Stress, coping, and health. In Rice, H. V. (Eds.) Handbook of stress, coping and health: Implications for nursing research, theory, and practice (pp.3-23). USA: Sage Publication, Inc.

Marshall, L. L., Allison, A., Nykamp, D., \& Lanke, S. (2008). Perceived stress and quality of life among doctor of pharmacy students. American Journal of Pharmaceutical Education, 72(6), 1-8.

Olff, M., Langeland, W., \& Gersons, B. P. (2005). Effects of appraisal and coping on the neuroendocrine response to extreme stress. Neuroscience $\mathcal{E}$ Biobehavioral Reviews, 29(3), 457-467. doi: 10.1016/j.neubiorev.2004.12.006.

Oswalt, S. B., \& Riddock, C. C. (2007). What to do about being overwhelmed: Graduate students, stress, and university services. College Student Affairs Journal, 27(1), 24-44.

Palmer, L. (2013). The relationship between stress, fatigue, and cognitive functioning. College Student Journal, 47(2), 312325.

Rafidah, K., Azizah, A., Norzaidi, M. D., Chong, S. C., Salwani, M. I., \& Noraini, I. (2009). Stress and academic performance: Empirical evidence from university students. Academy of Educational Leadership Journal, 13(1), 37-51.

Rice, V. H. (Ed.). (2011). Theories of stress and its relationship to health. In Rice, $\mathrm{H}$. V. (Eds.), Handbook of stress, coping, and health: Implications for nursing research, 
theory, and practice. USA: Sage Publication, Inc.

Schneiderman, N., Ironson, G., \& Siegel, S. D. (2004). Stress and health: Psychological, behavioral, and biological determinants. Annual review of clinical psychology, 1, 607-628. doi: 10.1146/ annurev.clinpsy.1.102803.144141

Schwabe, L., \& Wolf, O. T. (2012). Stress modulates the engagement of multiple memory systems in classification learning. The Journal of Neuroscience, 32(32), 11042-11049. doi: 10.1523/ jneurosci.1484-12.2012.

Serido, J., Almeida, D. M., \& Wethington, E. (2004). Chronic stressors and daily hassles: Unique and interactive relationships with psychological distress. Journal of Health and Social Behavior, 45(1), 17-33. doi: 10.1177/ 002214650404500102.

Spurgeon, A., Jackson, C. A., \& Beach, J. R. (2001). The life events inventory: Re-scaling based on an occupational sample. Occupational Medicine, 51(4), 287-293.

Staal, M. A. (2004). Stress, cognition, and human performance: A literature review and conceptual framework. Nasa technical memorandum, 212824, 9. http:// humanfactors.arc.nasa.gov/web/library/ publications/publications.php

Stallman, H. M. (2010). Psychological distress in university students: A comparison with general population data. Australian Psychologist, 45(4), 249257. doi: 10.1080/00050067.2010.482109.

Talib, N., \& Zia-ur-Rehman, M. (2012). Academic performance and perceived stress among university students. Educational Research and Reviews, 7(5), 127-132. doi: 10.5897/err10.192.

Thoits, P. A. (1994). Stress, coping, and social support processes: where are we? What next? Journal of Health And Social Behavior, 35, 53-79. http://www.jstor. org/stable/2626957.

Ursin, H., \& Eriksen, H. R. (2004). The cognitive activation theory of stress. Psychoneuroendocrinology, 29(5), 567-592. doi: 10.1016/S0306-4530(03)00091-X

Waqas, A., Khan, S., Sharif, W., Khalid, U., \& Ali, A. (2014). Association of academic stress with sleeping difficulties in medical students of a Pakistani medical school: a cross sectional survey. PeerJ, 211. doi: $10.7717 /$ peerj. 840 . 